Article

\title{
Bioinspired Heterocyclic Partnership in a Cyanine-Type Acidichromic Chromophore
}

\author{
Maria Laura Alfieri, Lucia Panzella ${ }^{\mathbb{D}}$, Marco d'Ischia $\mathbb{D}^{\mathbb{D}}$ and Alessandra Napolitano *(D) \\ Department of Chemical Sciences, University of Naples “Federico II", I-80126 Naples, Italy; \\ marialaura.alfieri@unina.it (M.L.A.); panzella@unina.it (L.P.); dischia@unina.it (M.d.) \\ * Correspondence: alesnapo@unina.it
}

Academic Editors: Ugo Caruso and Derek J. McPhee

Received: 25 July 2020; Accepted: 19 August 2020; Published: 21 August 2020

\begin{abstract}
A new red hair-inspired 1,4-benzothiazine-based scaffold is disclosed herein, built upon a modular D- $\pi$-A architecture via condensation of the easily accessible 3-phenyl-2H-1,4-benzothiazine with indole-3-carboxaldehyde. The compound was obtained in around $50 \%$ yields and was characterized by complete spectroscopic analysis. The new benzothiazine-based cyanine displayed a characteristic reversible acidichromic behavior with a marked bathochromic shift upon acidification. The chromophore resisted at least fifteen hydrochloric acid/sodium hydroxide cycles without appreciable alterations. The expedient and scalable synthetic procedure together with the $\mathrm{pH}$ sensitive chromophoric properties would make the new compound an attractive prototype for novel modular chromophore for $\mathrm{pH}$-sensing and other applications.
\end{abstract}

Keywords: benzothiazine-based chromophores; heterocyclic aromatic aldehyde; cyanine dyes; acidichromism; $\mathrm{pH}$ sensors

\section{Introduction}

The design and build-up of organic-based chromophores exhibiting tailored electronic and optical features has become an active research field over the past decade. Among different applications, particular interest has been focused on optoelectronics (e.g., dye sensitized solar cells, photo- and chemical-switching systems, organic light emitting devices) [1-5], organic electronics, such as organic semiconductors [6-9], imaging technologies (e.g., electrophotography, thermal printing, and ink-jet printing) [10], and biomedicine (e.g., fluorescent sensors and anticancer treatments or photodynamic therapy) [11-17].

In addition to chemical stability and intense absorption in the visible region, desirable properties of functional dyes include any change of the chromophoric properties, such as photochromism or solvatochromism, that is associated with a modification of the external parameters or aggregation state [18-22].

An interesting nature-inspired class of compounds featuring most of the requisites for technological applications are cyanine dyes, which are structurally related to the betacyanin pigments occurring in fruits and vegetables and exhibiting red purple chromophores. These dyes feature an imine and an enamine type site arranged to form a push-pull system. Because of their excellent photophysical properties, such as high molar extinction coefficients and high fluorescence quantum yields, outstanding biocompatibility, and low toxicity to living systems, cyanines are good candidates for developing chemosensors [23-26].

Recently, novel cyanine-type dyes, designated trichocyanines [27], have been built upon a modular $\mathrm{D}-\pi-\mathrm{A}$ architecture which incorporates ring systems inspired by the $\Delta^{2,2^{\prime}}$-bi-(2H-1,4-benzothiazine) structural core of trichochromes: unique $\mathrm{pH}$-dependent aminoacidic pigments occurring in red human hair and avian feathers [28-30] (Figure 1). The most characteristic feature of trichochromes is their 
doubly cross-conjugated yellow-to-red chromophore, which undergoes a marked bathochromic shift to an intense blue coloration in acid as a result of the protonation of the benzothiazine nitrogen that enhances its acceptor character [31-33].<smiles>C1=CC2N=CC(=C3C=Nc4ccccc4S3)SC2C=C1</smiles>

$\Delta^{2,2}$-bi-(2H-1,4-benzothiazine)<smiles>NC(CC1=CC2S/C(=C3/Sc4cc(CC(N)C(=O)O)ccc4NC3=O)C(=O)NC2C=C1)C(=O)O</smiles>

Trichochrome C

Figure 1. Representative structures of trichochromes.

The trichocyanines, in particular, showed an extension of the conjugated system compared to that exhibited by $\Delta^{2,2^{\prime}}$-bi-(2H-1,4-benzothiazine) [32,34], which expectedly resulted in a larger bathochromic shift in acid. Therefore, variation of the $\pi$-bridge could be recognized as a facile and effective approach for developing push-pull chromophores with specific properties and easy tunability by modulating the electron-donating substituent(s) on the phenyl ring (Figure 2).

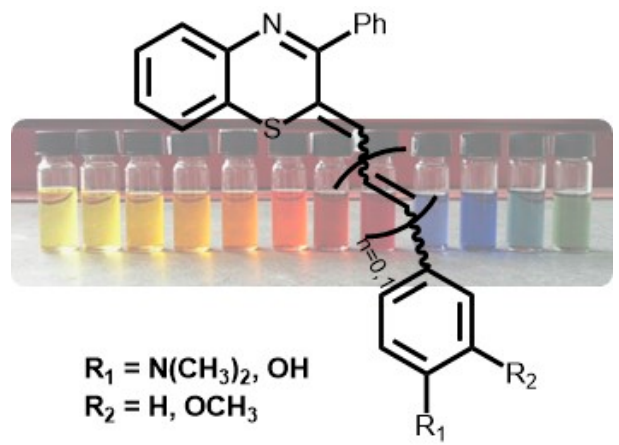

Figure 2. Structure of the trichocyanines synthesized and color variation associated to $\mathrm{pH}$ changes in the range 1-12 [27].

Starting from this background it was argued that novel functional chromophores could be obtained by reaction of the nucleophilic enamine-type $\mathrm{C} 2$ position of the $2 \mathrm{H}-1$,4-benzothiazine moiety [35-37] with carboxaldehydes of nitrogenous heterocyclic aromatic systems. This would allow the build-up of a variant of the benzothiazine-based cyanine chromophore, with the benzothiazine nitrogen acting as acceptor and the nitrogen of the heterocyclic aromatic system as donor component.

In this work this rationale was tested through the preparation and characterization of a new benzothiazine-based system by reaction of the easily accessible 3-phenyl-2H-1,4-benzothiazine [35] with indole-3-carboxaldehyde. The ease of the synthetic procedure and the peculiar acidichromic behavior open new perspectives for the design and exploitation of nature-inspired chromophores for technological applications.

\section{Results and Discussion}

\subsection{Synthesis and Structural Characterization of Cyanine $\mathbf{1}$}

First, the 3-phenyl-(2H)-1,4-benzothiazine was synthesized using a previously developed procedure [35] in which the $o$-aminothiophenol was reacted with phenacyl bromide in anhydrous diethyl ether. In $2 \mathrm{~h}$ a complete conversion of the starting materials was obtained and the compound separated from the reaction mixture as a yellow solid in pure form (ca. 80\% yields) (Scheme 1). 


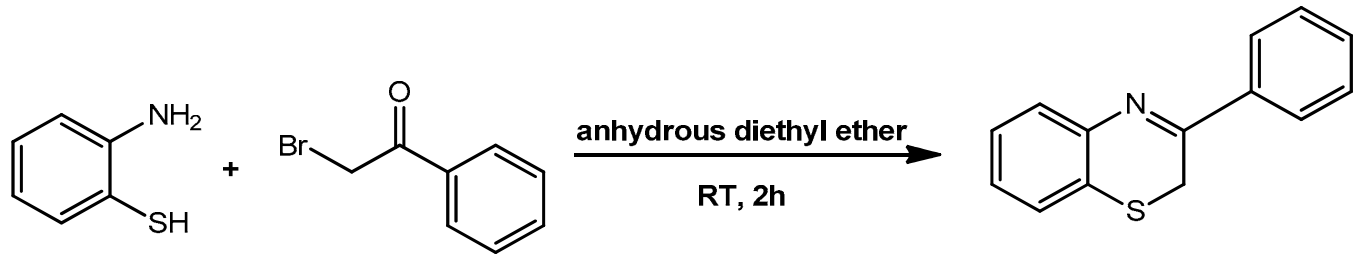

3-phenyl-(2H)-1,4-benzothiazine

Scheme 1. Synthesis of 3-phenyl-(2H)-1,4-benzothiazine.

In the first series of experiments, the reaction between 3-phenyl-2H-1,4-benzothiazine and indole-3-carboxaldehyde was optimized starting from the conditions previously developed for the reaction with benzaldehyde or cinnamaldehyde in acetonitrile in the presence of $\mathrm{HCl}$ [27] (Table 1). TLC analysis of the reaction mixtures using different amounts of the acid showed that concentrations as high as $2.5 \mathrm{M}$ were required to achieve a satisfactory and rapid consumption of the benzothiazine and to minimize by-product formation. In addition, the reaction proved faster, with an almost complete consumption of the starting reagent at $3 \mathrm{~h}$, at which point the temperature was raised from $25{ }^{\circ} \mathrm{C}$ to $70{ }^{\circ} \mathrm{C}$. Notably, this reaction time was significantly shorter than that used in previously reported procedures [27]. The stoichiometric ratio of the two reagents was varied in the range benzothiazine/aldehyde from 0.5:1 to 1:2. A 1:1.5 molar ratio proved to be an optimal condition to favor product formation over side reactions such as self-coupling of the benzothiazine.

Table 1. Optimization of reaction condition for the synthesis of cyanine 1 .

\begin{tabular}{ccccc}
\hline Entry & Benzothiazine/Aldehyde (Molar Ratio) & Solvent & Temperature $\left({ }^{\circ} \mathrm{C}\right)$ & Time $(\mathrm{h})$ \\
\hline 1 & $1: 1$ & $\mathrm{CH}_{3} \mathrm{CN} / 0.5 \mathrm{M} \mathrm{HCl}$ & r.t. & 24 \\
2 & $1: 1$ & $\mathrm{CH}_{3} \mathrm{CN} / 1.5 \mathrm{M} \mathrm{HCl}$ & r.t. & 24 \\
3 & $1: 1$ & $\mathrm{CH}_{3} \mathrm{CN} / 2.5 \mathrm{M} \mathrm{HCl}$ & r.t. & 24 \\
4 & $1: 1$ & $\mathrm{CH}_{3} \mathrm{CN} / 2.5 \mathrm{M} \mathrm{HCl}$ & 45 & 8 \\
5 & $1: 1$ & $\mathrm{CH}_{3} \mathrm{CN} / 2.5 \mathrm{M} \mathrm{HCl}$ & 70 & 3 \\
6 & $0.5: 1$ & $\mathrm{CH}_{3} \mathrm{CN} / 2.5 \mathrm{M} \mathrm{HCl}$ & 70 & 3 \\
7 & $1: 2$ & $\mathrm{CH}_{3} \mathrm{CN} / 2.5 \mathrm{M} \mathrm{HCl}$ & 70 & 3 \\
8 & $1: 1.5$ & $\mathrm{CH}_{3} \mathrm{CN} / 2.5 \mathrm{M} \mathrm{HCl}$ & 70 & 3 \\
\hline
\end{tabular}

On this basis, for synthetic purposes, the reaction was run on a preparative scale in $12 \mathrm{M}$ $\mathrm{HCl} /$ acetonitrile $1: 4 v / v$, at $70{ }^{\circ} \mathrm{C}$, starting from hundreds milligrams of 3-phenyl-(2H)-1,4-benzothiazine. After $3 \mathrm{~h} \mathrm{TLC}$ analysis showed the presence of a main component $\left(R_{\mathrm{f}}=0.42\right.$, eluant cyclohexane/ethyl acetate 8:2 $v / v)$ together with minor components. After removal of acetonitrile under reduced pressure, the aqueous acid mixture was extracted with ethyl acetate. The main product of the reaction, yellow in color, was isolated in pure form by silica gel column chromatography fractionation in around $50 \%$ yield and subjected to a complete spectroscopic characterization that led to its formulation as 2-((1H-indol-3-yl)methylene)-3-phenyl-2H-1,4-benzothiazine) (1) shown in Scheme 2.

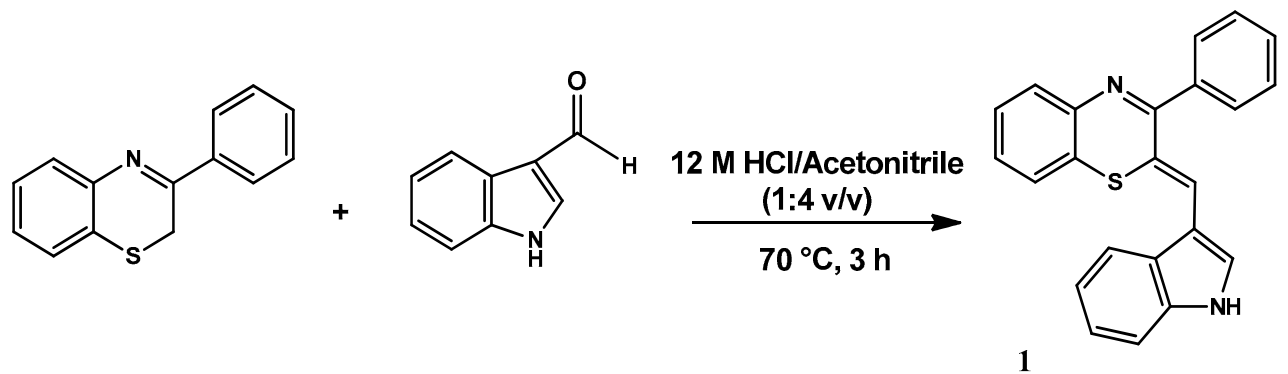

Scheme 2. Synthesis of 2-((1H-indol-3-yl)methylene)-3-phenyl-2H-1,4-benzothiazine) (1). 
MALDI mass spectrometry analysis in positive reflectron mode (Figure S1) indicated a pseudomolecular ion peak $[\mathrm{M}+\mathrm{H}]^{+}$at $m / z 353$, as expected for the condensation product 1 . Complete spectral characterization (Figures S2-S6) confirmed structure 1 proposed for the compound. The ${ }^{1} \mathrm{H}$ NMR spectrum (Figure S2) showed a well-defined pattern of resonances attributable to the 1,4-benzothiazine and indole moieties, the phenyl substituent, and the diagnostic singlet for the exocyclic double bond at $7.30 \mathrm{ppm}$. In addition, the NOESY spectrum (Figure S7) allowed the assignment of the $\mathrm{Z}$ configuration to the double bond formed in the condensation reaction, showing a cross-peak between the singlet at $7.30 \mathrm{ppm}$ and the multiplet at $7.82 \mathrm{ppm}$ due to the protons of the phenyl ring ortho to the substitution position. A 2D NMR analysis allowed complete assignment of proton and carbon resonances (Figure S8).

\subsection{Characterization of the $p H$-Dependent Chromophore}

The chromophoric properties of cyanine 1 were systematically investigated over the whole $\mathrm{pH}$ range. The cyanine proved freely soluble in organic solvents like chloroform or alcohols and also exhibited a good solubility in ethanol or methanol/water 70:30 and 50:50 mixtures. For the purpose of spectrophotometric experiments, a mother solution in methanol at $5 \mathrm{mM}$ was prepared and then properly diluted in the buffer solutions. At neutral pHs, absorption maxima centered at 332 and $444 \mathrm{~nm}$ were observed. At acidic $\mathrm{pH}$ below 3 the band at higher wavelength underwent a large bathochromic shift (544 $\mathrm{nm}$ ) and a marked hyperchromic effect (Figure 3). This shift is likely due to the protonation of the imine nitrogen of the benzothiazine moiety whose relatively high basicity stems from the stabilization of the resulting iminium ion provided by the indole nitrogen (Figure 3 ). The molar extinction coefficients $(\varepsilon)$ for the neutral $(444 \mathrm{~nm})$ and acid $(544 \mathrm{~nm})$ forms were found to be $5403 \pm 48 \mathrm{M}^{-1} \mathrm{~cm}^{-1}$ and $12461 \pm 29 \mathrm{M}^{-1} \mathrm{~cm}^{-1}$ respectively.

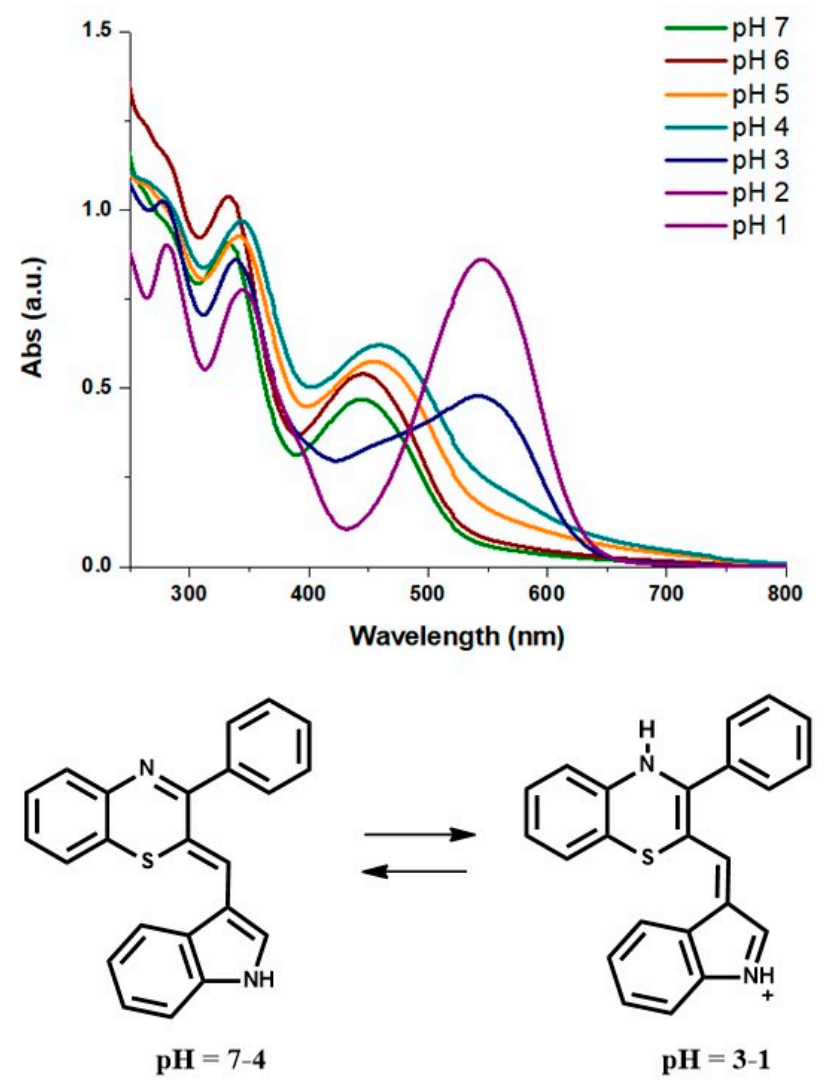

Figure 3. Top: UV-vis absorption spectra of cyanine 1 dissolved in methanol and diluted to $0.1 \mathrm{mM}$ in $50 \mathrm{mM}$ sodium phosphate buffer at different pHs. Bottom: protonation equilibrium of cyanine $\mathbf{1}$. 
Notably, the acid/base shift proved fully reversible over at least fifteen $\mathrm{HCl} / \mathrm{NaOH}$ addition cycles (Figure 4).
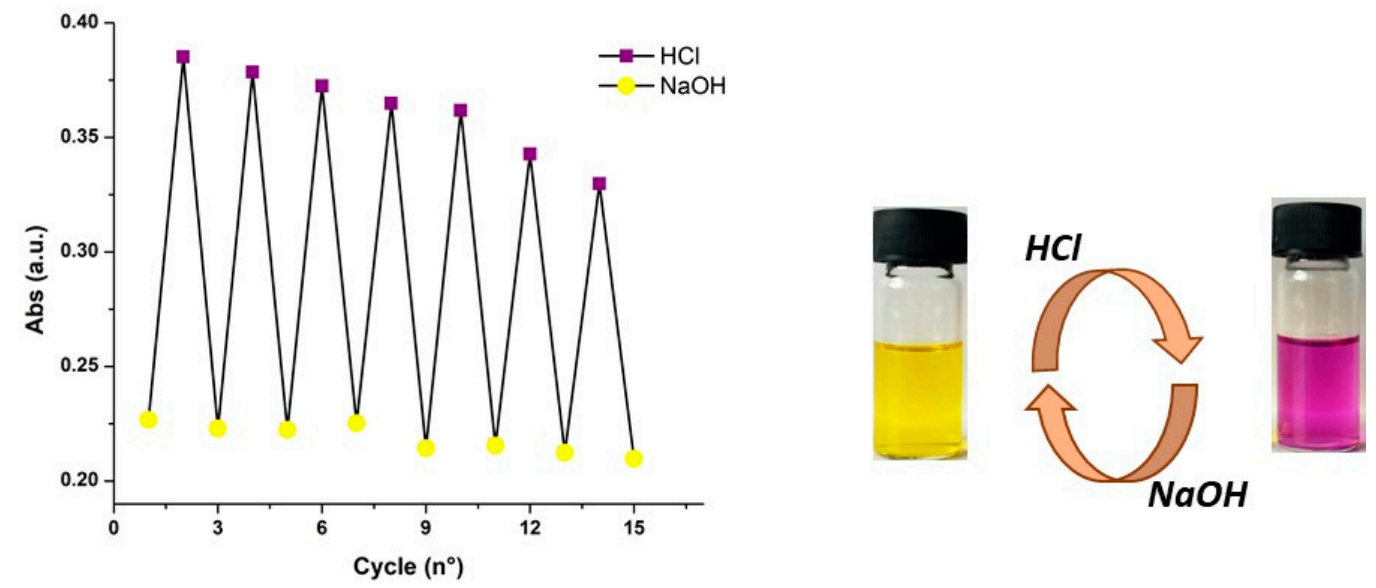

Figure 4. Changes of absorbance at $544 \mathrm{~nm}$ and digital pictures of 1 at $0.1 \mathrm{mM}$ following repeated sequential addition of $\mathrm{HCl}$ and $\mathrm{NaOH}$ solution, up to $\mathrm{pH} 2.0$ or 7.0 respectively.

The chromophore of the cyanine $\mathbf{1}$ in the neutral form proved to be affected by solvent changes only to a limited extent with a maximum bathochromic shift of around $15 \mathrm{~nm}$ passing from chloroform to water (Figure S9).

In other experiments the fluorescence properties of cyanine $\mathbf{1}$ at different $\mathrm{pHs}$ were also evaluated. The product showed a moderate fluorescence at $\mathrm{pH} 7.0$ by irradiation at $332 \mathrm{~nm}$ that was quenched in acid $(\mathrm{pH}=2.0)$, without the generation of any other fluorophore (Figure S10).

Cyanine $\mathbf{1}$ in methanol was easily deposited by spin coating onto different substrates (e.g., glass slides), yielding homogeneous thin films yellow in color which rapidly turned violet after exposure to gaseous hydrochloric acid (Figure 5). Notably, the shift proved to be completely reversible upon exposure to gaseous ammonia. Exposure to vapors of organic acids such as trifluoroacetic acid or acetic acid produced a similar though less marked color shift (Figure S11).
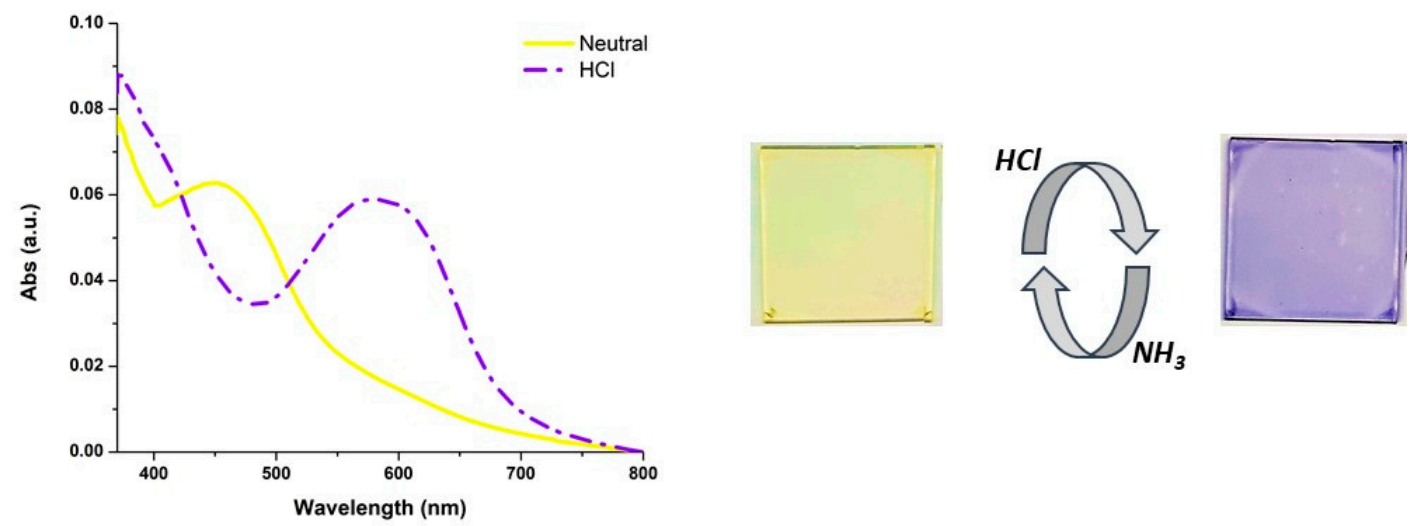

Figure 5. UV-vis spectra and digital pictures of glass slides coated with $\mathbf{1}(5 \mathrm{mM})$ before and after exposure to acidic vapors.

In further experiments the potential of cyanine $\mathbf{1}$ as dye was evaluated using materials much different in nature spanning from nylon to cotton and filter paper. As apparent from pictures in Figure 6 in all cases the materials were homogeneously dyed and underwent a rapid and well appreciable shift of the hue on exposure to acidic vapors. 
i)
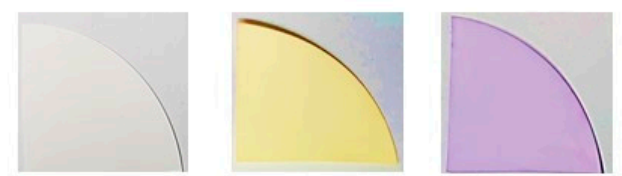

ii)
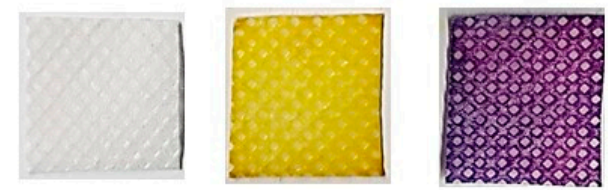

iii)
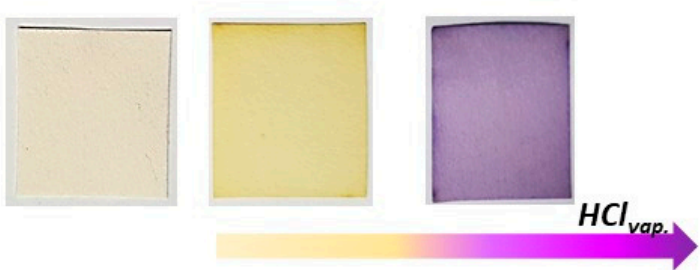

Figure 6. Nylon (i), cotton (ii), and filter paper (iii) dyed by dipping into a $5 \mathrm{mM}$ methanol solution of cyanine 1. Rows (i)-(iii): Left: before dyeing, middle: dyeing with 1; right: after exposure to acidic vapors.

\section{Materials and Methods}

Phenacyl bromide, indole-3-carboxaldehyde, and 2,5-dihydroxybenzoic acid were purchased from Sigma-Aldrich; o-aminothiophenol was purchased from Fluka. All solvents were obtained from Carlo Erba. Analytical TLC were carried out on silica gel plates $(0.25 \mathrm{~mm})$ from Merck using cyclohexane/ethyl acetate 8:2 $v / v$ as the eluent.

UV-vis spectra were recorded with a Jasco V-560 UV-vis spectrophotometer.

Fluorescence spectra were recorded with a Jasco FP-750 spectrofluorometer.

${ }^{1} \mathrm{H}$ NMR and ${ }^{13} \mathrm{C}$ NMR spectra were recorded in $\mathrm{CDCl}_{3}$ at $400 \mathrm{MHz}$ on a Bruker $400 \mathrm{MHz}$ spectrometer. ${ }^{1} \mathrm{H},{ }_{1} \mathrm{H}$ COSY, ${ }^{1} \mathrm{H},{ }^{13} \mathrm{C} \mathrm{HSQC}$, and ${ }^{1} \mathrm{H},{ }^{13} \mathrm{C} \mathrm{HMBC}$ were run at $400 \mathrm{MHz}$ using Bruker standard pulse programs.

Positive Reflectron MALDI spectra were recorded on an AB Sciex TOF/TOF 5800 instrument using 2,5-dihydroxybenzoic acid as the matrix. One milliliter of the analyte, dissolved in chloroform, was premixed with $1 \mathrm{~mL}$ of the matrix in a centrifuge tube, and then $2 \mu \mathrm{L}$ of the resulting mixture was pipetted on the MALDI target plate and air-dried for MALDI-ToF MS analysis. The laser was operated at $3700 \mathrm{~Hz}$ and the spectrum represented the sum of 15,000 laser pulses from randomly chosen spots per sample position. Raw data were analyzed using the computer software provided by the manufacturers and were reported as monoisotopic masses.

Spin-coating experiments were conducted with a spin-coater Laurell WS-650MZ-23NPP/LITE. The spin coating parameters were set as the following: $\alpha=500 \mathrm{rpm} / \mathrm{s}, \omega=2000 \mathrm{rpm}, \mathrm{t}=30 \mathrm{~s}$. Glass slides were cleaned by sonication in ethanol for $10 \mathrm{~min}$, then washed with isopropanol and dried with a compressed air flow.

\subsection{Synthesis of 3-Phenyl-(2H)-1,4-benzothiazine}

The 3-phenyl-(2H)-1,4-benzothiazine was prepared according to Santacroce et al. [35]. A solution of $o$-aminothiophenol $(1.1 \mathrm{~mL}, 8.7 \mathrm{mmol})$ in anhydrous ethyl ether $(5 \mathrm{~mL})$ was treated at room temperature with a solution of phenacyl bromide $(2.2 \mathrm{~g}, 11 \mathrm{mmol})$ in anhydrous ethyl ether $(25 \mathrm{~mL})$ under magnetic stirring for $2 \mathrm{~h}$. The yellow solid that separated was filtered, washed with ethyl ether, and then dried under vacuum to give the pure product ( $82 \%$ yield). The purity was checked by ${ }^{1} \mathrm{H}$ NMR analysis. 


\subsection{Synthesis of 2Z-((1H-Indol-3-yl)methylene)-3-phenyl-2H-1,4-benzothiazine)}

3-phenyl-2H-1,4-benzothiazine (200 $\mathrm{mg}, 0.62 \mathrm{mmol}$ ) dissolved in acetonitrile/12 M hydrochloric acid $(4: 1 v / v)(16 \mathrm{~mL})$ was treated with indole-3-carboxaldehyde $(103 \mathrm{mg}, 0.89 \mathrm{mmol})$ under stirring at $70{ }^{\circ} \mathrm{C}$ for $3 \mathrm{~h}$. After $3 \mathrm{~h}$, at complete consumption of the benzothiazine (TLC analysis), acetonitrile was removed under reduced pressure and the mixture was extracted with ethyl acetate $(3 \times 50 \mathrm{~mL})$. The organic layers were dried over anhydrous sodium sulphate and taken to dryness. The residue thus obtained $(150 \mathrm{mg})$ was dissolved in chloroform $(2 \mathrm{~mL})$ and fractionated by silica gel column chromatography (eluent cyclohexane/ethyl acetate 80:20 $v / v)$ to give $\mathbf{1}$ in pure form (120 $\mathrm{mg}, 55 \%$ yield).

$\mathrm{UV}: \lambda_{\max }\left(\mathrm{CH}_{3} \mathrm{OH}\right) 332 \mathrm{~nm}, 444 \mathrm{~nm}$; MALDI-MS: $\mathrm{C}_{23} \mathrm{H}_{16} \mathrm{~N}_{2} \mathrm{~S} m / z 353\left([\mathrm{M}+\mathrm{H}]^{+}\right) ;{ }^{1} \mathrm{H}$ NMR $\left(\mathrm{CDCl}_{3}\right)$ $\delta(\mathrm{ppm}): 7.07(\mathrm{~m}, 1 \mathrm{H}), 7.10(\mathrm{~m}, 1 \mathrm{H}), 7.20(\mathrm{~m}, 3 \mathrm{H}), 7.30(\mathrm{~s}, 1 \mathrm{H}), 7.40(\mathrm{~m}, 2 \mathrm{H}), 7.49(\mathrm{~d}, 4 \mathrm{H}), 7.82(\mathrm{~m}, 2 \mathrm{H})$, 7.95 (s, 1H), $7.99(\mathrm{~s}, 1 \mathrm{H}) ;{ }^{13} \mathrm{C}$ NMR $(\mathrm{CDCl} 3) \delta(\mathrm{ppm}): 111.3(\mathrm{CH}), 111.4(\mathrm{CH}), 112.3(\mathrm{C}), 117.1(\mathrm{C})$, $118.3(\mathrm{CH}), 120.4(\mathrm{CH}), 123.0(\mathrm{C}), 123.5(\mathrm{C}), 124.4(\mathrm{CH}), 126.0(\mathrm{CH}), 126.1(\mathrm{CH}), 126.7(\mathrm{CH}), 127.1(\mathrm{C})$, $127.3(\mathrm{CH}), 128.4(\mathrm{CH} \times 2), 129.3(\mathrm{CH} \times 2), 129.4(\mathrm{CH}), 129.8(\mathrm{CH}), 135.3(\mathrm{C}), 140.4(\mathrm{C}), 162.6(\mathrm{C})$.

\subsection{Film Formation with $\mathbf{1}$ and Dyeing Experiments}

Cyanine $\mathbf{1}$ dissolved in methanol at $5 \mathrm{mM}$ was deposited on glass slides using a spin-coater. For dyeing experiments, the proper fabric was dipped into a solution of $\mathbf{1}$ in methanol at $5 \mathrm{mM}$ for $1 \mathrm{~min}$ and then allowed to dry in air. In all cases the dyed materials were exposed to acid vapors at room temperature (12 M HCl, trifluoroacetic acid, glacial acetic acid).

\section{Conclusions}

In recent years cyanine dyes have largely been exploited as biological reporters and in other technological applications by virtue of their peculiar chromophoric and fluorescence properties. Inspired by $\Delta^{2,2^{\prime}}$-bibenzothiazine photochromic and acidichromic chromophore of red human hair pigments trichochromes, a new class of cyanine dyes termed trichocyanines was designed in which a highly tunable cyanine-type chromophore was implemented using the benzothiazine nitrogen as the acceptor moiety at high basicity, allowing for a marked bathochromic shift even at slightly acidic pHs. Herein we have synthesized a new 1,4-benzothiazine based cyanine chromophore by condensation of indole-3-carboxaldehyde with 3-phenyl-1,4-benzothiazine at the nucleophilic 2 position. The cyanine thus obtained, characterized as $2 \mathrm{Z}-((1 \mathrm{H}-$-indol-3-yl)methylene)-3-phenyl-2H-1,4-benzothiazine) by complete spectral analysis, exhibited a reversible acidichromic behavior with a marked bathochromic shift upon acidification from yellow $(444 \mathrm{~nm}$ at neutral $\mathrm{pH})$ to violet $(544 \mathrm{~nm}$ at $\mathrm{pH} 2)$ with molar extinction coefficient in the order of $12,000 \mathrm{M}^{-1} \mathrm{~cm}^{-1}$ (acid form). The ease and scalability of the synthetic procedures and the preliminary assessment of the dyeing ability of the cyanine would encourage exploitation of the new acidichromic system as a core unit for $\mathrm{pH}$ sensing devices and related applications. The results reported herein are also of interest for the possibility of developing adhesive formulations of the reported cyanine involving, e.g., mussel-inspired polydopamine films and related coatings, in order to assess their possible exploitation for $\mathrm{pH}$ sensing on various surfaces underwater.

Supplementary Materials: The following are available online, Figure S1: Segmental spectrum of MALDI-ToF ( $m / z: 250-800 \mathrm{Da}$ ) characterization of compound 1. Figure S2: ${ }^{1} \mathrm{H}$ NMR spectrum of $\mathbf{1}$ in $\mathrm{CDCl}_{3}$. Figure S3: ${ }^{13} \mathrm{C}$ NMR spectrum of compound 1 in $\mathrm{CDCl}_{3}$. Figure $\mathrm{S4}$ : ${ }^{1} \mathrm{H},{ }_{1}^{1} \mathrm{H}$ COSY spectrum of compound $\mathbf{1}\left(\mathrm{CDCl}_{3}\right)$. Figure S5: ${ }^{1} \mathrm{H}_{,}^{13} \mathrm{C}$ HSQC spectrum of compound $\mathbf{1}\left(\mathrm{CDCl}_{3}\right)$. Figure $\mathrm{S} 6:{ }^{1} \mathrm{H},{ }^{13} \mathrm{C} \mathrm{HMBC}$ spectrum of compound $\mathbf{1}\left(\mathrm{CDCl}_{3}\right)$. Figure S7: NOESY spectrum of compound $1\left(\mathrm{CDCl}_{3}\right)$. Figure $\mathrm{S8}:{ }^{1} \mathrm{H}$ (black) and ${ }^{13} \mathrm{C}$ (red) NMR resonances of cyanine 1. Figure S9: UV-vis absorption spectra of cyanine $\mathbf{1}(100 \mu \mathrm{M})$ in different organic solvents. Figure S10: Emission spectra of the neutral and protonated forms of cyanine 1. Figure S11: UV-vis spectra and digital pictures of glass slides, coated with $\mathbf{1}$, after exposure to acidic vapors.

Author Contributions: Conceptualization, A.N. and L.P.; methodology, M.L.A.; investigation, M.L.A.; data curation, M.L.A.; writing—original draft preparation, A.N.; writing—review and editing, M.d. All authors have read and agreed to the published version of the manuscript.

Funding: This research received no external funding. 
Acknowledgments: M.d. thanks the 2017YJMPZN PRIN project "MUSSEL" for financial support.

Conflicts of Interest: The authors declare no conflict of interest.

\section{References}

1. Pepe, G.; Cole, J.M.; Waddell, P.G.; McKechnie, S. Molecular engineering of cyanine dyes to design a panchromatic response in co-sensitized dye-sensitized solar cells. Mol. Syst. Des. Eng. 2016, 1, 86-98. [CrossRef]

2. Liu, H.; Liao, X.; Li, X.; Wu, D.; Guo, Q.; Wu, J.; Qian, S.; Lan, J.; Wang, R.; You, J. Molecular design of new organic sensitizers based on thieno[1,4]benzothiazine for dye-sensitized solar cells. RSC Adv. 2015, 5, 56865-56871. [CrossRef]

3. Lerch, M.M.; Medved, M.; Lapini, A.; Laurent, A.D.; Iagatti, A.; Bussotti, L.; Szymański, W.; Jan Buma, W.; Foggi, P.; Di Donato, M.; et al. Tailoring photoisomerization pathways in donor-acceptor stenhouse adducts: The role of the hydroxy group. J. Phys. Chem. A 2018, 122, 955-964. [CrossRef] [PubMed]

4. Lin, S.L.; Kuo, P.Y.; Yang, D.Y. Design and synthesis of a coumarin-based acidichromic colorant. Molecules 2007, 12, 1316-1324. [CrossRef] [PubMed]

5. Liu, X.Y.; Ge, H.T.; Zhao, Y.; Zhao, D.; Fan, J.; Liao, L.S. Novel carbazole derivatives designed by an ortho-linkage strategy for efficient phosphorescent organic light-emitting diodes. J. Mater. Chem. C 2018, 6, 4300-4307. [CrossRef]

6. Gsänger, M.; Bialas, D.; Huang, L.; Stolte, M.; Würthner, F. Organic semiconductors based on dyes and color pigments. Adv. Mater. 2016, 28, 3615-3645. [CrossRef]

7. Wang, X.; Liu, H.; Wu, J.; Xie, Z.; Zhang, Q. Synthesis and photovoltaic properties of new conjugated polymers based on red hair pigment skeleton. Dyes Pigm. 2019, 160, 823-829. [CrossRef]

8. Luo, S.M.; Stellmach, K.A.; Ikuzwe, S.M.; Cao, D.D. Redox-active heteroacene chromophores derived from a nonlinear aromatic diimide. J. Org. Chem. 2019, 84, 10362-10370. [CrossRef]

9. Cai, K.; Xie, J.; Yang, X.; Zhao, D. Heterohexacene diimides: Anti- and syn-isomers and quinonoid forms. Org. Lett. 2014, 16, 1852-1855. [CrossRef]

10. Yu, Z.; Wu, Y.; Xiao, L.; Chen, J.; Liao, Q.; Yao, J.; Fu, H. Organic phosphorescence nanowire lasers. J. Am. Chem. Soc. 2017, 139, 6376-6381. [CrossRef]

11. Bonaccorsi, P.; Papalia, T.; Barattucci, A.; Salerno, T.M.G.; Rosano, C.; Castagnola, P.; Viale, M.; Monticone, M.; Campagna, S.; Puntoriero, F. Localization-controlled two-color luminescence imaging via environmental modulation of energy transfer in a multichromophoric species. Dalton Trans. 2018, 47, 4733-4738. [CrossRef] [PubMed]

12. Guan, Y.; Zhang, Y.; Zou, J.; Huang, L.P.; Chordia, M.D.; Yue, W.; Wu, J.J.; Pan, D.F. Synthesis and biological evaluation of genistein-IR783 conjugate: Cancer cell targeted delivery in MCF-7 for superior anti-cancer therapy. Molecules 2019, 24, 4120. [CrossRef] [PubMed]

13. Yang, X.G.; Mou, Y.H.; Wang, Y.J.; Wang, J.; Li, Y.Y.; Kong, R.H.; Ding, M.; Wang, D.; Guo, C. Design, synthesis, and evaluation of monoamine oxidase a inhibitors-indocyanine dyes conjugates as targeted antitumor agents. Molecules 2019, 24, 1400. [CrossRef] [PubMed]

14. Zhang, Y.; Bi, J.; Xia, S.; Mazi, W.; Wan, S.; Mikesell, L.; Rudy, L.L.; Liu, H. A near-infrared fluorescent probe based on a FRET rhodamine donor linked to a cyanine acceptor for sensitive detection of intracellular $\mathrm{pH}$ alternations. Molecules 2018, 23, 2679. [CrossRef] [PubMed]

15. James, N.S.; Cheruku, R.R.; Missert, J.R.; Sunar, U.; Pandey, R.K. Measurement of cyanine dye photobleaching in photosensitizer cyanine dye conjugates could help in optimizing light dosimetry for improved photodynamic therapy of cancer. Molecules 2018, 23, 1842. [CrossRef]

16. Ahoulou, E.O.; Drinkard, K.K.; Basnet, K.; St. Lorenz, A.; Taratula, O.; Henary, M.; Grant, K.B. DNA photocleavage in the near-infrared wavelength range by 2-quinolinium dicarbocyanine dyes. Molecules 2020, 25, 2926. [CrossRef]

17. Lin, C.M.; Usama, S.M.; Burgess, K. Site-specific labeling of proteins with near-IR heptamethine cyanine dyes. Molecules 2018, 23, 2900. [CrossRef]

18. Zhang, Y.; Yuan, L.; Jia, S.; Liu, X.; Zhao, J.; Yin, G. Dicyanovinyl substituted push-pull chromophores: Effects of central $\mathrm{C}=\mathrm{C} /$ phenyl spacers, crystal structures and application in hydrazine sensing. Phys. Chem. Chem. Phys. 2019, 21, 3218-3226. [CrossRef] 
19. Šarlah, D.; Juranovič, A.; Kožar, B.; Rejc, L.; Golobič, A.; Petrič, A. Synthesis of naphthalene-based push-pull molecules with a heteroaromatic electron acceptor. Molecules 2016, 21, 267. [CrossRef]

20. Jin, R.; Zhang, X.; Xiao, W. Theoretical studies of photophysical properties of D- $\pi-\mathrm{A}-\pi-\mathrm{D}$-type diketopyrrolopyrrole-based molecules for organic light-emitting diodes and organic solar cells. Molecules 2020, 25, 667. [CrossRef]

21. Gayton, J.N.; Autry, S.; Fortenberry, R.C.; Hammer, N.I.; Delcamp, J.H. Counter anion effect on the photophysical properties of emissive indolizine-cyanine dyes in solution and solid state. Molecules 2018, 23, 3051. [CrossRef] [PubMed]

22. El-Shishtawy, R.M.; Oliveira, A.S.; Almeida, P.; Ferreira, D.P.; Conceição, D.S.; Ferreira, L.F.V. Photophysical studies of a new water soluble indocarbocyanine dye adsorbed onto microcrystalline cellulose and beta-cyclodextrin. Molecules 2013, 18, 5648-5668. [CrossRef] [PubMed]

23. Mukhopadhyay, A.; Mandal, K.J.; Narasimha Moorthy, J. Anionic merocyanine dyes based on thiazol-2-hydrazides: Reverse solvatochromism, preferential solvation and multiparametric approaches to spectral shifts. Phys. Chem. Chem. Phys. 2018, 20, 4149-4159. [CrossRef] [PubMed]

24. Sun, W.; Guo, S.; Hu, C.; Fan, J.; Peng, X. Recent development of chemosensors based on cyanine platforms. Chem. Rev. 2016, 116, 7768-7817. [CrossRef]

25. Schwechheimer, C.; Rönicke, F.; Schepersb, U.; Wagenknecht, H.A. A new structure-activity relationship for cyanine dyes to improve photostability and fluorescence properties for live cell imaging. Chem. Sci. 2018, 9, 6557-6563. [CrossRef]

26. Soriano, E.; Holder, C.; Levitz, A.; Henary, M. Benz[c,d]indolium-containing monomethine cyanine dyes: Synthesis and photophysical properties. Molecules 2016, 21, 23. [CrossRef]

27. Leone, L.; Pezzella, S.; Crescenzi, O.; Napolitano, A.; Barone, V.; d'Ischia, M. Trichocyanines: A red-hair-inspired modular platform for dye-Based one-time-pad molecular cryptography. ChemistryOpen 2015, 4, 370-377. [CrossRef]

28. Napolitano, A.; Panzella, L.; Leone, L.; d'Ischia, M. Red hair benzothiazines and benzothiazoles: Mutation-inspired chemistry in the quest for functionality. Acc. Chem. Res. 2013, 46, 519-528. [CrossRef]

29. Simon, J.D.; Peles, D.N. The red and the black. Acc. Chem. Res. 2010, 43, 1452-1460. [CrossRef]

30. Napolitano, A.; De Lucia, M.; Panzella, L.; d'Ischia, M. The “Benzothiazine" chromophore of pheomelanins: A reassessment. Photochem. Photobiol. 2008, 84, 593-599. [CrossRef]

31. Napolitano, A.; Di Donato, P.; Prota, G. Zinc-catalyzed oxidation of 5-S-cysteinyldopa to 2,2'-bi(2H-1,4benzothiazine): Tracking the biosynthetic pathway of trichochromes, the characteristic pigments of red hair. J. Org. Chem. 2001, 66, 6958-6966. [CrossRef] [PubMed]

32. Leone, L.; Crescenzi, O.; Napolitano, A.; Barone, V.; d'Ischia, M. The $\Delta^{2,2^{\prime}}$-bi(2H-1,4-benzothiazine) structural motif of red hair pigments revisited: Photochromism and acidichromism in a unique four-state system. Eur. J. Org. Chem. 2012, 27, 5136-5140. [CrossRef]

33. Ye, T.; Lamb, L.E.; Wakamatsu, K.; Ito, S.; Simon, J.D. Ultrafast absorption and photothermal studies of decarboxytrichochrome $C$ in solution. Photochem. Photobiol. Sci. 2003, 2, 821-823. [CrossRef] [PubMed]

34. Leone, L.; Crescenzi, O.; Amorati, R.; Valgimigli, L.; Napolitano, A.; Barone, V.; d'Ischia, M. Red-hair-inspired chromogenic system based on a proton-switched dehydrogenative free-radical coupling. Org. Lett. 2013, 15, 4944-4947. [CrossRef]

35. Santacroce, C.; Sica, D.; Nicolaus, R.A. Sintesi di 1,4-benzotiazine. Gazz. Chim. Ital. 1968, 98, 85-96.

36. MacKenzie, N.E.; Thomson, R.H.; Greenhalgh, C.W. New dyes based on 3-aryl-benzo- and -naphtho1,4-thiazines. J. Chem. Soc. Perkin Trans. 1 1980, 1, 2923-2932. [CrossRef]

37. Lin, Y.M.; Lu, G.P.; Wang, R.K.; Yi, W.B. Radical route to 1,4-benzothiazine derivatives from 2-aminobenzenethiols and ketones under transition-metal-free. Org. Lett. 2016, 18, 6424-6427. [CrossRef]

Sample Availability: Samples of the compounds 3-phenyl-(2H)-1,4-benzothiazine and 2Z-((1H-indol-3yl)methylene)-3-phenyl-2H-1,4-benzothiazine) are available from the authors.

(C) 2020 by the authors. Licensee MDPI, Basel, Switzerland. This article is an open access article distributed under the terms and conditions of the Creative Commons Attribution (CC BY) license (http://creativecommons.org/licenses/by/4.0/). 